\title{
The application of modified cenospheres in DeNOx process
}

\author{
Bogdan Samojeden ${ }^{1, *}$, Teresa Grzybek $^{1}$, Agnieszka Szymaszek $^{1}$, Oliwia Ligęza ${ }^{1}$, Wioletta \\ Kowalczyk $^{1}$, and Monika Motak ${ }^{1}$ \\ ${ }^{1}$ AGH University of Science and Technology, Al. Mickiewicza 30, 30-059 Kraków, Poland
}

\begin{abstract}
Cenospheres were modified with iron, manganese and/or copper ions by the hydrotalcite method. The obtained catalysts were characterized by FTIR, XRD and low-temperature nitrogen sorption. The best catalyst at low temperature $\left(200{ }^{\circ} \mathrm{C}\right)$ was $\mathrm{CBFe}-\mathrm{Mn}$ while at the highest measured temperature of $500{ }^{\circ} \mathrm{C}$ both $\mathrm{CBFe}-\mathrm{Mn}$ and $\mathrm{CBMn}-\mathrm{Cu}$ showed similar performance.
\end{abstract}

\section{Introduction}

The application of hard coal as an energy source, in addition to a significant amount of particulate matter, also results in introducing other pollutants into the environment, mainly $\mathrm{SO}_{2}$ and NOx. The latter are particularly harmful for both people and environment, and the amount of emitted $\mathrm{NO}_{\mathrm{x}}$ are regulated by the Directive of the European Parliament and of the Council of 14 December 2016 on the reduction of national emissions of certain atmospheric pollutants [1]. In order to reduce NOx emissions from power plants and industrial boilers, apart from primary methods, whose effectiveness is not sufficient, additional technologies are used [2-6]: SCR (selective catalytic reduction), SNCR (selective non-catalytic reduction) and hybrid technologies SNCR-SCR. SCR is the most effective method of removing NOx from flue gases, but requires a suitable catalyst. The catalyst currently used in power industry is $\mathrm{V}_{2} \mathrm{O}_{5}$ supported on $\mathrm{TiO}_{2}$ and promoted with $\mathrm{WO}_{3}$, placed on a monolith. However, this catalyst has a number of disadvantages, among others high activity is achieved only in the medium-temperature range (about $300-400^{\circ} \mathrm{C}$ ), and at higher temperatures the structure of the support is changed [7]. The catalyst also contains environmentally harmful vanadium. Because of these disadvantages, new catalysts for the SCR process are still searched. Those investigated in the literature are most often oxides of transition metals applied on an oxide support, usually with the addition of promoters increasing their thermal and / or chemical stability. Numerous systems have been proposed as catalyst carriers, e.g. activated carbons [8-17], aluminosilicates [18-22], zeolites [23-26], hydrotalcites [27-29], etc. Most often, delectron metals, such as Fe [20,22,30-33], $\mathrm{Cu}$ [5,18,34-38], Mn [8,39-43], etc. were studied as active materials. The catalysts based on activated carbons showed appropriate of NO conversion in the low to medium-temperature range $\left(150-300^{\circ} \mathrm{C}\right)$, but are prone to oxidation $[3,9,10,44]$. Promoted aluminosilicates have good catalytic properties at the high temperature

\footnotetext{
* Corresponding author: Bogdan.Samojeden@agh.edu.pl
} 
range [18,22,45-48]. Numerous hydrotalcite-like materials or their derivatives have been reported as catalysts for a wide variety of chemical processes including selective reduction of nitrogen oxides with ammonia (SCR, DeNOx). Due to the high content of silicate and aluminosilicate, cenospheres obtained from fly ashes may be an interesting carrier.

The global production of fly ash is estimated at around 4.2 billion tons per year, the largest of which is produced in China and the United States [49]. Annually, about 20 million tonnes of energy waste are generated in Poland [50], with only 4-9\% being subject to use [49]. One of the components of fly ash are cenospheres whose content is in the range of $0.3-2 \mathrm{wt} . \%$. They are formed at high temperatures and are therefore thermally stable. The size of the cenospheres is in the range of $0.01-350 \mu \mathrm{m}$, dependent on the $\mathrm{SiO}_{2} / \mathrm{Al}_{2} \mathrm{O}_{3}$ ratio [37,51-54]. The high $\mathrm{SiO}_{2}$ content results in the formation of small-scale cenospheres. The sintering temperature also has a large influence on the size of the microspheres, the higher the temperature, the larger the diameters. The composition and structure of the cenospheres is important and influences their use. The outer part has a glassy and crystalline structure. The glassy phase is dominant and consists of silicon and aluminium oxides, and smaller amounts of iron and calcium oxides. The crystalline phase consists mainly of quartz and mullite, as well as hematite and magnetite [54]. The typical composition of the solid phase cenospheres is [55]: $\mathrm{SiO}_{2}(50 \%-65 \%), \mathrm{Al}_{2} \mathrm{O}_{3}(19 \%-42 \%), \mathrm{Fe}_{2} \mathrm{O}_{3}(0.7 \%-6.5 \%)$. There are also: $\mathrm{CaO}$, $\mathrm{MgO}, \mathrm{K}_{2} \mathrm{O}, \mathrm{Na}_{2} \mathrm{O}, \mathrm{TiO}_{2}, \mathrm{SO}_{3}$ and $\mathrm{P}_{2} \mathrm{O}_{5}$ in negligible amounts [55]. The interior of the cenosphere is mainly filled with $\mathrm{CO}_{2}$ and $\mathrm{N}_{2}$ gas, but also $\mathrm{CO}, \mathrm{O}_{2}$ and $\mathrm{H}_{2} \mathrm{O}$ in smaller quantities [53,55]. Cenospheres also have low density $\left(0.2-0.8 \mathrm{~g} / \mathrm{cm}^{3}\right)$ and very good mechanical strength $\left(210-350 \mathrm{~kg} / \mathrm{cm}^{2}\right)$. They exhibit good corrosion resistance, including an oxidizing environment, as well as high resistance to thermal shock. These properties result from high mullite content in the cenospheres. Microspheres tend to sinter only at temperatures of $950^{\circ} \mathrm{C}$ to $1200^{\circ} \mathrm{C}$ and melt at a temperature of $1250^{\circ} \mathrm{C}$ to $1450^{\circ} \mathrm{C}$ [56].

The main aim of this work was to study the possibility of using cenospheres modified with copper or iron as catalysts in the selective catalytic reduction of NO with ammonia SCR$\mathrm{NH}_{3}$. So-promoted materials were characterized by FTIR, X-ray diffraction, and the lowtemperature nitrogen sorption.

\section{Experimental part}

\subsection{Synthesis of catalysts}

White cenospheres (Cenospheres Trade \& Engenering), further denoted $C B$, studied here were used as supports. The cenospheres were modified with $\mathrm{Cu}, \mathrm{Mn}$ and/or $\mathrm{Cu}$, using a method similar to that applied for hydrotalcites formation (precipitation at constant $\mathrm{pH}$ ). The resulting materials were then calcined at $500{ }^{\circ} \mathrm{C}$ for $12 \mathrm{~h}$.

The following catalysts were obtained:

- $\mathrm{CBFe}-\mathrm{Mn}$ - white cenosphere modified with $\mathrm{Fe}^{2+}$ and $\mathrm{Mn}^{2+}$

- $\mathrm{CBFe}-\mathrm{Cu}$ - white cenosphere modified with $\mathrm{Fe}^{2+}$ and $\mathrm{Cu}^{2+}$

- $\mathrm{CBMn}-\mathrm{Cu}$ - white cenosphere modified with $\mathrm{Mn}^{2+}$ and $\mathrm{Cu}^{2+}$.

\subsection{Characterization}

The crystalline structure of the catalysts was determined by X-ray diffraction XRD using PANalytical Empyrean diffractometer $(\mathrm{CuK} \alpha, \lambda=0.15406 \mathrm{~nm})$. Diffractograms were recorded in the range of $2 \theta$ angles from 5 to $90^{\circ}$, with a measurement step of $0.02^{\circ} / \mathrm{min}$. The measurements were taken at room temperature. 
The FTIR spectroscopy (Perkin Elmer Frontier FT-IR) was used to determine the functional groups. Spectra were recorded in the $4000-400 \mathrm{~cm}^{-1}$ range, with a resolution of 4 $\mathrm{cm}^{-1}$.

The specific surface area was determined using low-temperature nitrogen sorption (ASAP 2060 by Micrometrics). Before the measurement, the catalysts were degassed at $500{ }^{\circ} \mathrm{C}$. All physicochemical tests were performed for the samples after calcination.

\subsection{Catalytic tests}

The reaction of selective catalytic reduction NO with ammonia was carried out in a fixed bed reactor in a setup shown in Fig. 1, with the following parameters: catalyst mass $200 \mathrm{mg}$; composition of reaction gases $800 \mathrm{ppm} \mathrm{NO}, 800 \mathrm{ppm} \mathrm{NH}_{3}$ and $3 \% \mathrm{O}_{2}$; temperature range $200-500{ }^{\circ} \mathrm{C}$ with measurement every $100{ }^{\circ} \mathrm{C}$; flow $100 \mathrm{ml} / \mathrm{min}$.

The concentration of $\mathrm{NO}$ and $\mathrm{N}_{2} \mathrm{O}$ was determined at the outlet of the reactor using an ABB IR analyzer.

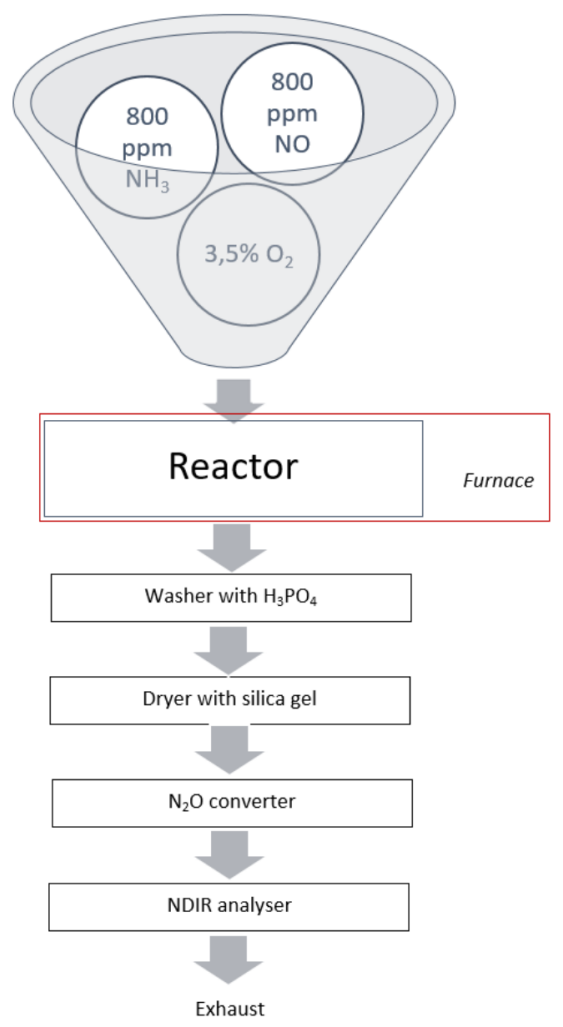

Fig. 1 Schema of SCR apparatus

NO conversion $\mathrm{x}(\mathrm{NO})$ was calculated according to the formula:

$$
x(N O)=\frac{c_{N O \text { initial }}-c_{N O \text { final }}}{c_{N O \text { initial }}} \cdot 100 \%
$$

\section{Results and discussion}


Fig. 2 shows the diffractograms for the modified cenospheres. The resulting XRD patterns are typical for cenospheres [46], [47] and indicate the presence of mullite $\left(\mathrm{Al}_{2} \mathrm{O}_{3}\right)(2 \theta=41$; $\left.43 ; 61 ; 65^{\circ}\right)$, quartz $\left(\mathrm{SiO}_{2}\right)\left(2 \theta=26 ; 47 ; 56^{\circ}\right)$, hematite $\left(\mathrm{Fe}_{2} \mathrm{O}_{3}\right)\left(2 \theta=35^{\circ}\right)$, and magnetite $\left(\mathrm{Fe}_{3} \mathrm{O}_{4}\right)\left(2 \theta=33^{\circ}\right)$. After modification, no additional phases of iron, manganese and/or copper were found, which indicates either the formation of amorphous forms of active materials introduced and/or a high degree of dispersion of the deposited compounds [57].

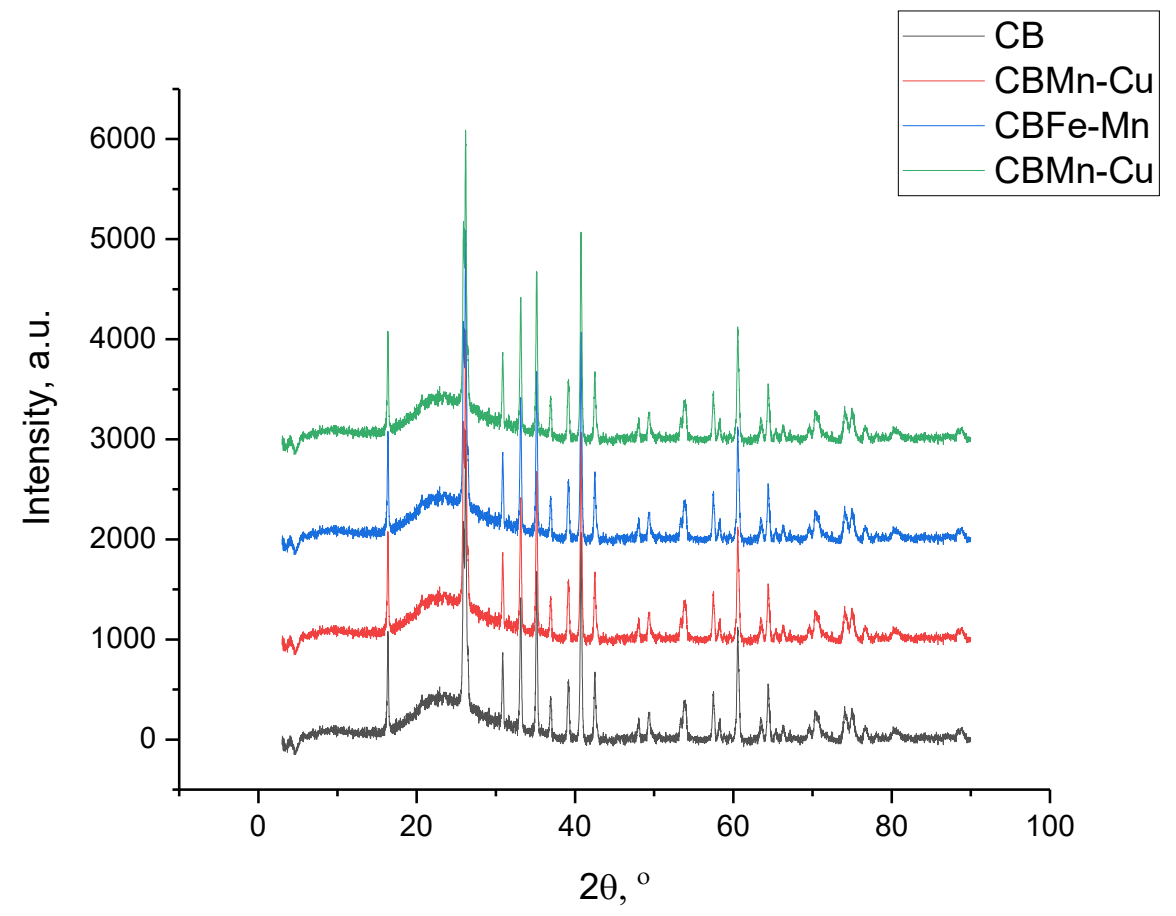

Fig. 2. XRD patterns of modified cenospheres

The infrared absorption spectra were typical for cenospheres, showing bounds of Si-O$\mathrm{Si}, \mathrm{Si}-\mathrm{O}-\mathrm{Al}$ and Al-O. The introduction of active material did not affect either the intensity, or did not result in the formation of additional peaks [58-60].

The textural tests have shown that the obtained systems were characterized by small BET surface area (about $10 \mathrm{~m}^{2} / \mathrm{g}$ ) and small pore volume values (Table 1).

Table 1 Textural parameters of obtained catalysts

\begin{tabular}{|l|c|c|c|}
\hline Sample & $\begin{array}{c}\text { Specific surface } \\
\mathbf{a r a}, \mathbf{~ m}^{\mathbf{2}} / \mathbf{g}\end{array}$ & $\begin{array}{c}\text { Volume of micropores, } \\
\mathbf{c m}^{\mathbf{3}} / \mathbf{g}\end{array}$ & $\begin{array}{c}\text { Pore width, } \\
\mathbf{~ n m ~}\end{array}$ \\
\hline $\mathrm{CB}$ & 2 & 0.005 & 2.01 \\
\hline $\mathrm{CBFe}-\mathrm{Cu}$ & 12 & 0.007 & 12.08 \\
\hline $\mathrm{CBFe}-\mathrm{Mn}$ & 14 & 0.008 & 12.45 \\
\hline $\mathrm{CBMn}-\mathrm{Cu}$ & 13 & 0.010 & 12.55 \\
\hline
\end{tabular}


$\square \mathrm{CBFe}-\mathrm{Mn} \quad \mathrm{CBFe}-\mathrm{Cu} \square \mathrm{CBMn}-\mathrm{Cu}$

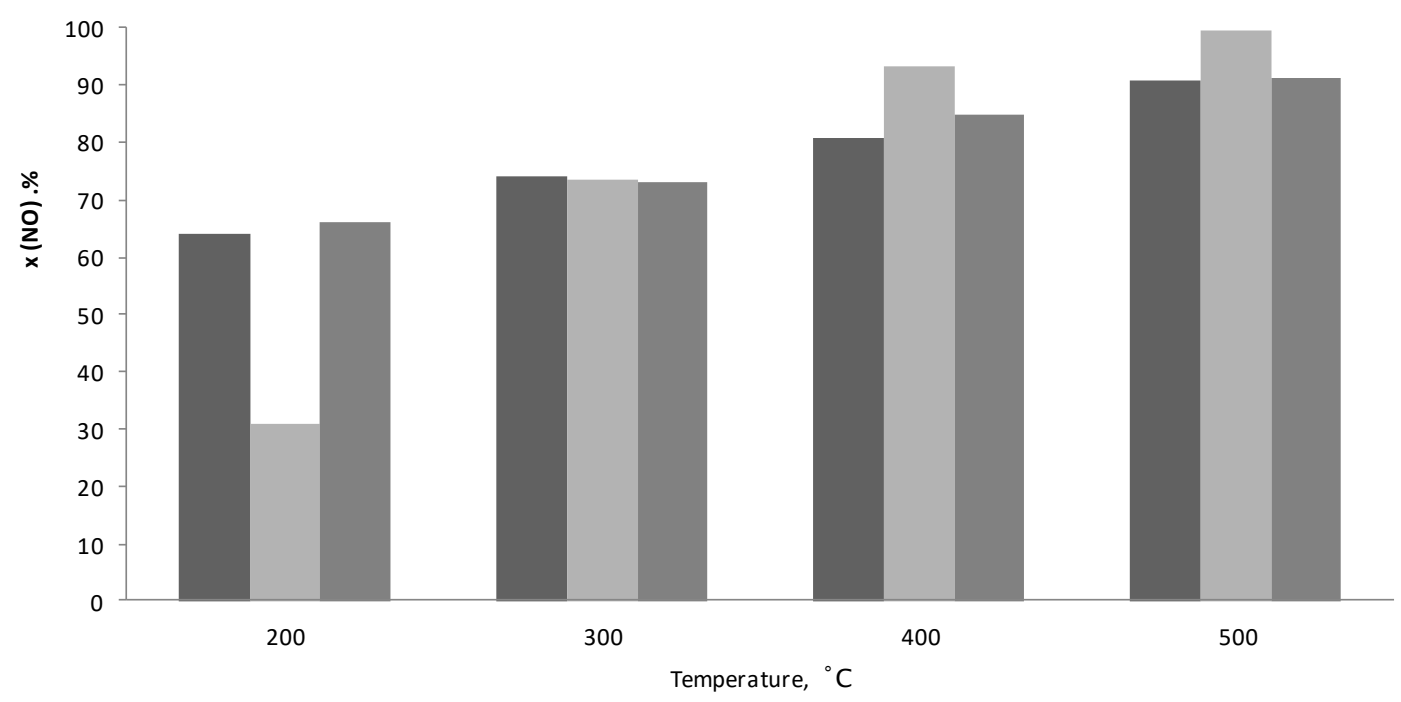

Fig. 3 NO conversion $\mathrm{x}(\mathrm{NO})$ of the tested catalysts. Reaction conditions: $200 \mathrm{mg}$ cat.; 800 ppm NO, $800 \mathrm{ppm} \mathrm{NH} 3$ and $3 \% \mathrm{O}_{2} ;$ He rest; flow $100 \mathrm{ml} / \mathrm{min}$.

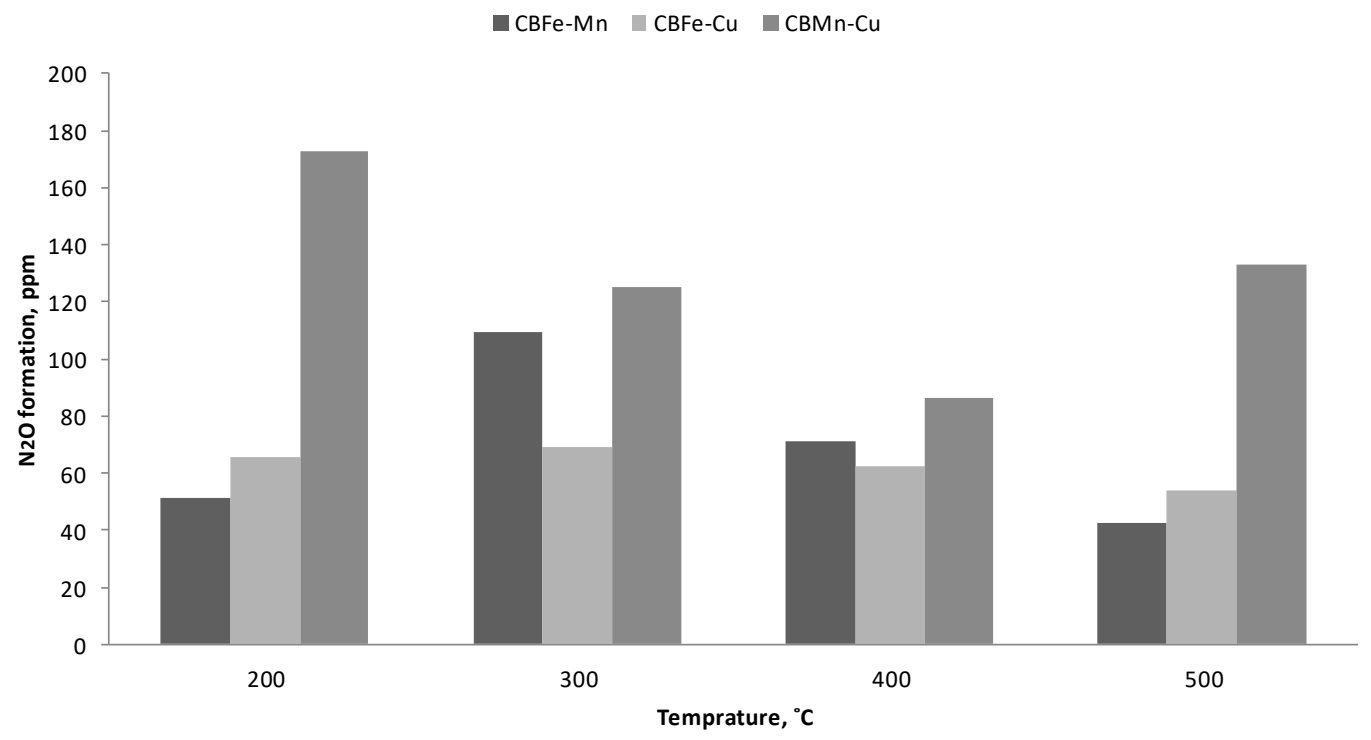

Fig. $4 \mathrm{~N}_{2} \mathrm{O}$ formation. Reaction conditions: $200 \mathrm{mg}$ cat.; 800 ppm NO, 800 ppm $\mathrm{NH}_{3}$ and 3\% $\mathrm{O}_{2}$; $\mathrm{He}$ rest; flow $100 \mathrm{ml} / \mathrm{min}$.

Fig. 3 presents NO conversion of the obtained catalysts tested in the $\mathrm{SCR}-\mathrm{NH}_{3}$ reaction, while Fig. 4 shows the amount of formed nitrous oxide. 
For the $\mathrm{CBFe}-\mathrm{Cu}$ catalyst, the $\mathrm{NO}$ conversion increased with temperature, and reached the value close to $100 \%$ at the highest tested temperature $\left(500{ }^{\circ} \mathrm{C}\right)$. Other tested catalysts obtained somewhat lower $\mathrm{x}(\mathrm{NO})$. In the case of manganese-modified catalysts, higher amounts of nitrous oxide were observed than for $\mathrm{CBFe}-\mathrm{Cu}$. This in good agreement with the performance of $\mathrm{MnOx}$-containing activated carbons [8] or hydrotalcites [61]. On the other hand, the lower amount of $\mathrm{N}_{2} \mathrm{O}$ formed for $\mathrm{CBFe}-\mathrm{Cu}$ agrees well with other Fe-containing types of catalysts $[4,22]$. It should be mentioned, however, that the values for $\mathrm{CBFe}-\mathrm{Mn}$ and $\mathrm{CBFe}-\mathrm{Cu}$ are only slightly over the experimental error of the used analyser (ca. $30 \mathrm{ppm}$ ). Taking into account both $\mathrm{NO}$ conversion and $\mathrm{N}_{2} \mathrm{O}$ formation, the best catalysts at low temperature $\left(200{ }^{\circ} \mathrm{C}\right)$ was $\mathrm{CBFe}-\mathrm{Mn}$ while at the highest measured temperature of $500{ }^{\circ} \mathrm{C}$ both $\mathrm{CBFe}-\mathrm{Mn}$ and $\mathrm{CBMn}-\mathrm{Cu}$ had similar efficiency. At $300^{\circ} \mathrm{C}$, NO conversion was similar for all studied samples but because of the lowest formation of $\mathrm{N}_{2} \mathrm{O}, \mathrm{CBFe}-\mathrm{Cu}$ was the best.

Taking into account the registered results and additionally the fact that cenospheres are obtained from waste (fly ash), it makes them promising materials for new DeNOx catalysts.

This work was supported by the AGH Research Grant No. 16.16.210.476

\section{References}

1. The European Parliament and the Council of the European Union, Directive (EU) 2016/2284 of the European Parliament and of the Council on the Reduction of National Emissions of Certain Atmospheric Pollutants (2016)

2. H. J. Seong, Selective Catalytic Reduction (SCR) of NO by NH 3 in a Fixed-bed Reactor, The Pennsylvania State University, State College, PA, 2012

3. B. Samojeden, M. Motak, and T. Grzybek, Comptes Rendus Chim. 18, 1049 (2015)

4. B. Samojeden and T. Grzybek, Energy 116, 1484 (2016)

5. A. Łamacz, A. Krztoń, and G. Djéga-Mariadassou, Appl. Catal. B Environ. 142-143, $268(2013)$

6. F. Gao, X. Tang, H. Yi, S. Zhao, C. Li, J. Li, Y. Shi, and X. Meng, Catalysts 7, 199 (2017)

7. J. Hagen, Industrial Catalysis: A Practical Approach, 2nd ed. (WILEY-VCH Verlag GmbH \& Co. KGaA, Weinheim, Germany, 2006)

8. J. Klinik, B. Samojeden, T. Grzybek, W. Suprun, H. Papp, and R. Gläser, Catal. Today 176, $303(2011)$

9. T. Grzybek, J. Klinik, and B. Samojeden, Gospod. Surowcami Miner. 23, 133 (2007)

10. B. Samojeden, J. Klinik, T. Grzybek, and H. Papp, Gospod. Surowcami Miner. 24, 295 (2008)

11. M. Saad, A. Białas, B. Samojeden, and M. Motak, in Contemp. Probl. Power Eng. Environ. Prot. (2017), pp. 173-182

12. R. Pietrzak and T. J. Bandosz, Carbon N. Y. 45, 2537 (2007)

13. K. Świrk, M. Rønning, and B. Samojeden, in Wspótczesne Probl. Energ. III, edited by K. Pikoń and M. Czop (Gliwice, 2015), pp. 151-162

14. T. Valdés-Solís, G. Marbán, and A. B. Fuertes, Appl. Catal. B Environ. 46, 261 (2003)

15. G. Marbán, A. Fuertes, and D. Nevskaia, Carbon N. Y. 38, 2167 (2000)

16. J. Zawadzki and M. Wisniewski, Carbon N. Y. 41, 2257 (2003)

17. B. Samojeden and T. Grzybek, Adsorpt. Sci. Technol. 35, 572 (2017)

18. B. Samojeden and M. Możdżeń, E3S Web Conf. 2020, 1 (2017)

19. M. Motak, Ł. Kuterasiński, P. Da Costa, and B. Samojeden, Comptes Rendus Chim. 18, $1106(2015)$

20. P. Ziemiański, K. Kałahurska, and B. Samojeden, Adsorpt. Sci. Technol. 35, 825 (2017)

21. L. Chmielarz, P. Kuśtrowski, Z. Piwowarska, B. Dudek, B. Gil, and M. Michalik, Appl. 
Catal. B Environ. 88, 331 (2009)

22. L. Chmielarz, M. Wojciechowska, M. Rutkowska, A. Adamski, A. Węgrzyn, A. Kowalczyk, B. Dudek, P. Boroń, M. Michalik, and A. Matusiewicz, Catal. Today 191, 25 (2012)

23. J. A. Loiland and R. F. Lobo, J. Catal. 311, 412 (2014)

24. M. Rutkowska, A. Borcuch, A. Marzec, A. Kowalczyk, B. Samojeden, J. M. Moreno, U. Díaz, and L. Chmielarz, Microporous Mesoporous Mater. (2018)

25. J. Goscianska, P. Bazin, O. Marie, M. Daturi, I. Sobczak, and M. Ziolek, Catal. Today 119, 78 (2007)

26. J. Goscianska and M. Ziolek, Catal. Today 137, 197 (2008)

27. M. Jabłońska and R. Palkovits, Catal. Sci. Technol. 6, 49 (2015)

28. M. Jabłońska, L. Chmielarz, and A. Wegrzyn, Copernican Lett. 4, 59 (2013)

29. T. Wongkerd, A. Luengnaruemitchai, and S. Jitkarnka, Appl. Catal. B Environ. 78, 101 (2008)

30. A. Quintanilla, J. A. Casas, and J. J. Rodríguez, Appl. Catal. B Environ. 76, 135 (2007)

31. P. Boroń, L. Chmielarz, J. Gurgul, K. Łatka, T. Shishido, J. M. Krafft, and S. Dzwigaj, Appl. Catal. B Environ. 138-139, 434 (2013)

32. T. Grzybek, Wegle Aktywne Promowane Fe3+ Jako Katalizatory Redukcji Tlenku Azotu Amoniakiem, Zeszyty Na (Uczelniane Wydawnictwo Naukowo-Dydaktyczne AGH, Kraków, 1993)

33. A. Boubnov, H. Lichtenberg, S. Mangold, and J.-D. Grunwaldt, J. Phys. Conf. Ser. 430, 2 (2013)

34. R. Martínez-Franco, M. Moliner, and A. Corma, J. Catal. 319, 36 (2014)

35. K. H. Chuang, C. Y. Lu, M. Y. Wey, and Y. N. Huang, Appl. Catal. A Gen. 397, 234 (2011)

36. F. Fan, Q. Zhang, X. Wang, Y. Ni, Y. Wu, and Z. Zhu, Fuel 186, 11 (2016)

37. B. Samojeden, J. Drużkowska, D. Duraczyńska, M. Poddębniak, and M. Motak, Przem. Chem. 1, 55 (2019)

38. A. Łamacz, A. Krztoń, and G. Djéga-Mariadassou, Catal. Today 176, 126 (2011)

39. T. Grzybek, J. Klinik, B. Dutka, H. Papp, and V. Suprun, Catal. Today 101, 93 (2005)

40. L. Chmielarz, R. Dziembaj, T. Grzybek, J. Klinik, T. Lojewski, D. Olszewska, and H. Papp, Catal. Letters 68, 95 (2000)

41. G. Marbán and A. B. Fuertes, Appl. Catal. B Environ. 34, 43 (2001)

42. T. Grzybek, M. Rogóż, and H. Papp, Catal. Today 90, 61 (2004)

43. Y. Su, B. Fan, L. Wang, Y. Liu, B. Huang, M. Fu, L. Chen, and D. Ye, Catal. Today 201, 115 (2013)

44. R. Pietrzak, K. Jurewicz, P. Nowicki, K. Babeł, and H. Wachowska, Fuel 86, 1086 (2007)

45. J. Muñiz, J. E. Herrero, and A. B. Fuertes, Appl. Catal. B Environ. 18, 171 (1998)

46. H. P. Boehm and S. Matzner, Carbon N. Y. 36, 1697 (1998)

47. E. Pollak, G. Salitra, A. Soffer, and D. Aurbach, Carbon N. Y. 44, 3302 (2006)

48. O. Duman, S. Tunç, and T. G. Polat, Appl. Clay Sci. 109-110, 22 (2015)

49. M. Wójcik, F. Stachowicz, and A. Masłoń, J. Civ. Eng. Environ. Archit. 64, 377 (2017)

50. M. Ahmad, Bud. o Zoptymalizowanym Potencjale Energ. 2, 67 (2017)

51. W. Pichór, K. Mars, E. Godlewska, and R. Mania, Kompozyty 149 (2010)

52. V. Fenelov, M. Mel'gunov, and V. N. Parmon, KONA Power Part. J. 189 (2010)

53. J. Bardło, Uszlachetnione Mikrosfery Glinokrzemianowe Jako Napetniacz Kompozytów Polimerowych (Kraków, 2016)

54. E. Haustein and B. Quant, Gospod. Surowcami Miner. 27, 95 (2011)

55. F. Plewa, M. Popczyk, and Z. Masłek, Polityka Energ. 10, 391 (2007)

56. M. Żyrkowski, R. Costa, L. F. Santos, and K. Witkowski, Fuel 174, 49 (2016) 
57. P. Bindu and S. Thomas, J. Theor. Appl. Phys. 8, 123 (2014)

58. K. Neha and K. Balasubramanian, RSC Adv. 4, 47529 (2014)

59. I. P. Lisovskii, V. G. Litovchenko, V. G. Lozinskii, and G. I. Steblovskii, Thin Solid Films 213, 164 (1992)

60. X. G. Cao and H. Y. Zhang, Electron. Mater. Lett. 8, 519 (2012)

61. D. Wierzbicki, R. Dębek, J. Szczurowski, S. Basąg, M. Włodarczyk, M. Motak, and R. Baran, Comptes Rendus Chim. 18, 1074 (2015) 